\title{
Effect of 2-O-Benzoyl para-Substituents on Glycosylation Rates
}

\author{
Lulu Teressa Poulsen, Mads Heuckendorff, and Henrik H. Jensen*(1) \\ Department of Chemistry, Aarhus University, Langelandsgade 140, 8000 Aarhus C, Denmark
}

\section{Supporting Information}

ABSTRACT: From a series of competition experiments, we have explored the degree to which various para-substituents ( $\mathrm{CN}, \mathrm{Br}, \mathrm{H}, \mathrm{OMe}$, pyrrolidino) of a 2-O-benzoyl functionalized glucosyl donor of the thioglycoside type affect the rate of glycosylation under $\mathrm{N}$-iodosuccinimide/triflic acid activation. As expected, electron-withdrawing groups were found to decrease the rate of glycosylation, whereas electron-donating groups resulted in the opposite outcome, underscoring the influence on the reaction rate exerted by a participating group. On this basis, a Hammett linear free-energy relationship was established $\left(R^{2}=0.979, \rho=0.6\right)$, offering fundamental insight into the magnitude of anchimeric assistance in glycosylation chemistry.

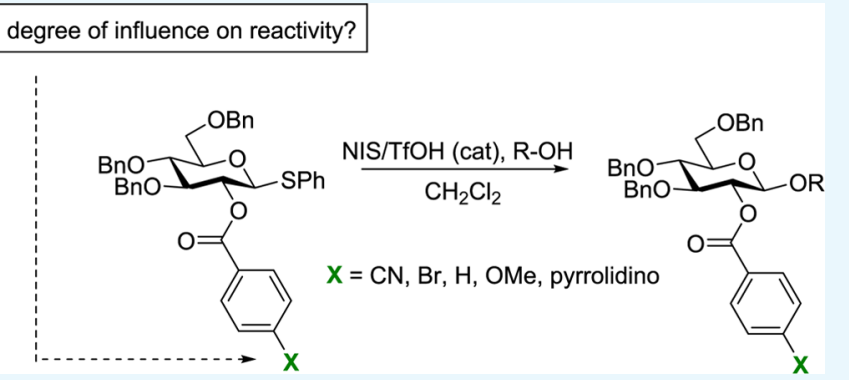

\section{INTRODUCTION}

It is well established that the inductive effect exerted by an ether group is smaller compared to an ester group. ${ }^{1}$ This makes it intuitive to understand the difference in reactivity between the classically armed and disarmed donors (being perbenzylated and peracylated, respectively) given the nature of the high-energy electron-deficient oxacarbenium ion-like transition state. $^{2}$ Upon construction of glycosyl donors with mixed protecting groups, e.g., of both ether and ester type, ${ }^{3}$ the level of reactivity is no longer so clear.

Earlier results by Fraser-Reid, ${ }^{2}$ Ley, ${ }^{4 \mathrm{a}}$ Wong, ${ }^{4 \mathrm{~b}}$ and their respective co-workers have demonstrated that knowing the precise order of reactivity as a function of protecting groups can be a valuable tool for streamlining saccharide assembly in that it allows one-pot multistep reactions.

We have elaborated on Wong's work by fine-tuning the reactivity of armed donors by using electron-rich $p$ methoxybenzyl ethers and electron-poor $p$-chloro and $p$ cyanobenzyl ethers as protective groups, which enabled us to perform the first armed-disarmed couplings among benzylated glycosyl donors. ${ }^{5}$

The presence of a participating ester group, e.g., 2-Obenzoyl, can have both an arming effect originating from anchimeric assistance, if the C-1-leaving group is trans to the C-2 substituent, but also an opposing disarming effect due to the strong electron-withdrawing nature of an ester. ${ }^{6}$ We have confirmed reports by the Demchenko group ${ }^{7}$ that a significantly higher level of reactivity (superarmament) ${ }^{8}$ can be achieved for an $S$-benzoxazolyl glucosyl donor carrying a 2$O$-benzoyl group under dimethyl(methylthio)sulfonium triflate activation (Figure 1A). We, however, also found that this is not general because both the same and analogous building blocks bearing SPh and SEt donor functionalities were less reactive than their traditionally armed tetra-O-benzylated counterparts with $\mathrm{N}$-iodosuccinimide/triflic acid (NIS/TfOH) activation

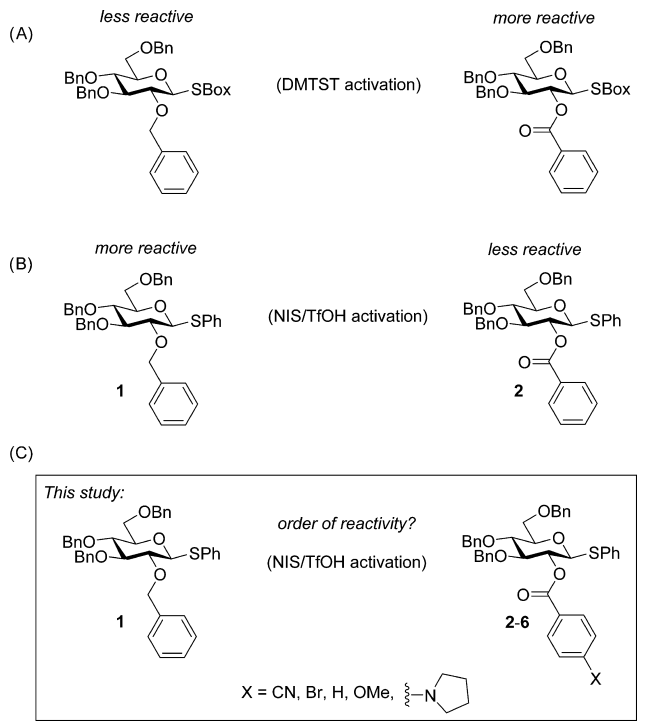

Figure 1. Current study $(\mathrm{C})$ in relation to previous findings (A and B).

(Figure 1B). These results have demonstrated that two opposing effects operate (anchimeric and electron-withdrawing) and contribute in varying degrees to the overall reactivity depending on the donor and promoter systems. ${ }^{9}$

This article describes our attempts to control and fine-tune the reactivity of a SPh-functionalized glucosyl donor by changing the para-substituent of a 2-O-benzoyl-protecting group (Figure 1C). This would provide insight into the

Received: May 2, 2018

Accepted: June 8, 2018

Published: June 29, 2018 
sensitivity to anchimeric assistance and possibly lead to a superarmed glucosyl donor with NIS/TfOH activation.

We anticipate that electron-donating groups like methoxy (OMe) would be accelerating in terms of both being better equipped for performing anchimeric assistance than with $\mathrm{H}$ in place of OMe, but also possess a reduced deactivating effect due to a decreased electron-withdrawing influence.

\section{RESULTS AND DISCUSSION}

To systematically investigate the influence of a 2-O-benzoyl para-substituent on the glycosyl donor reactivity, we set out to synthesize a range of donors with varying substituents being both electron-withdrawing $(\mathrm{CN}, \mathrm{Br})$ and electron-donating (OMe, pyrrolidino).

The target glycosyl donors 3-6 (Scheme 1) were prepared from $2-\mathrm{OH}$ thioglucoside 7 by first synthesizing the target

\section{Scheme 1. Synthesis of Glycosyl Donors Using Palladium-} Catalyzed Reactions
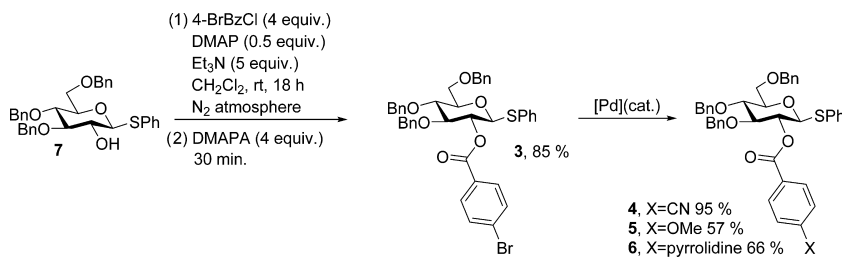

molecule 3 via reaction with $p$-bromobenzoyl chloride using our method for easy removal of excess acylating reagent with 3(dimethylamino)-1-propylamine (DMAPA). ${ }^{10}$ Cyano- and methoxybenzoyl-protected donors 4 and $\mathbf{5}$ were synthesized from 3 by a procedure similar to those previously described by us for the conversion of 4-chlorobenzyl ethers to 4methoxybenzyl $1^{11,12}$ and 4-cyanobenzyl ethers ${ }^{13}$ using a commercially available palladium precatalyst system and ligands developed by the Buchwald group. ${ }^{14}$ For the amination with pyrrolidine, the palladium precatalyst RuPhos Pd G3 was chosen and successfully yielded aniline 6 (Scheme 1).

After having prepared the range of target glycosyl donors with different 2-O-protection, their performance in glycosylation reactions with L-menthol under NIS/TfOH promotion was investigated. All the donors $(\mathbf{1}-\mathbf{6})$ were found to easily activate under the reaction conditions and good and reproducible yields were obtained (see the Supporting Information). Next, to evaluate the reactivity of the glycosyl donors, each of the 2-O-benzoylated thioglucosides (3-6) were set to compete against tetra- $O$-benzylated thioglucoside (1) for a limiting amount of NIS. More specifically, the experiments were performed by mixing the two competing donors ( 1 equiv. of each) and checking that their molar ratio was 1.0:1.0 by ${ }^{13} \mathrm{C}-\mathrm{NMR}$ spectroscopy by comparing C-1 resonances. ${ }^{15}$ Next, excess acceptor (L-menthol, 5 equiv.) and promoter (NIS, 1 equiv.) were added to the donor mixture. The reaction was initiated at $-78{ }^{\circ} \mathrm{C}$ by the addition of a catalytic amount of triflic acid ( $\mathrm{TfOH}, 0.1$ equiv.) and the reaction mixture was allowed to warm to $0{ }^{\circ} \mathrm{C}$ over $3 \mathrm{~h}$. After reaction completion and work-up, another ${ }^{13} \mathrm{C}$-NMR spectrum of the crude reaction mixture was recorded and the anomeric signals again compared. The postreaction ratio of unreacted donors is a direct result of the reactivity difference between the competing donors because a smaller amount of the less reactive donor will be consumed and vice versa. The reactions were carried out several times and, as previously established, found to give highly reproducible results.

The results from the conducted competition experiments can be seen in Table 1 . The nature of the 2-O-benzoyl para-

Table 1. Competition Experiments Between Glycosyl Donors (Conditions: 1 Equiv. NIS, 0.1 Equiv. TfOH, 5 Equiv. L-Menthol, -78 to $0{ }^{\circ} \mathrm{C}, 3 \mathrm{~h}$ )

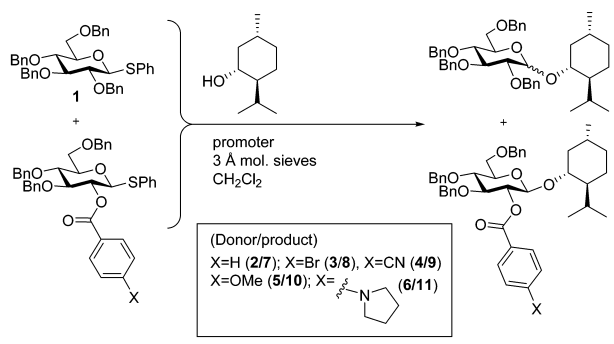

\begin{tabular}{|c|c|c|}
\hline Entry & Competition Experiment & $\begin{array}{c}\text { Reactivity Ratio, RR } \\
\text { (reciprocal ratio) }\end{array}$ \\
\hline 1 & 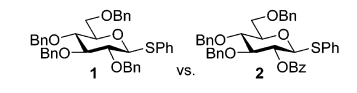 & $\begin{array}{c}1: 1.9 \\
(0.5: 1)\end{array}$ \\
\hline 2 & ${ }_{1}^{\mathrm{OBn}} \mathrm{BPh}$ vs. & $\begin{array}{l}1: 2.9 \\
(0.3: 1)\end{array}$ \\
\hline 3 & OBn vs. & $\begin{array}{c}1: 4.3 \\
(0.2: 1)\end{array}$ \\
\hline 4 & ${ }_{1}^{\mathrm{OBn}} \mathrm{sph}$ vs. & $\begin{array}{l}1: 1.6 \\
(0.6: 1)\end{array}$ \\
\hline 5 & 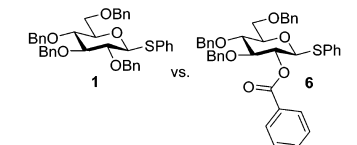 & $\begin{array}{l}1: 0.6 \\
(1.6: 1)\end{array}$ \\
\hline 6 & ${ }_{2}^{\mathrm{BBz}} \mathrm{Sph}$ & $\begin{array}{l}1: 0.7 \\
(1.5: 1)\end{array}$ \\
\hline
\end{tabular}

substituents were found to have a measureable impact on the reactivity of the glycosyl donors, as also previously observed for the analogous para-substituted benzyl ethers. ${ }^{5}$ The order of reactivity was as expected according to the electron-withdrawing/donating power of the substituents. Under the NIS/ $\mathrm{TfOH}$ activation used in this study, not even the more reactive $p$-methoxybenzoylated donor was as reactive as the tetra- $O$ benzylated donor 6 (entry 4).

The most reactive donor was found to be the $p$-pyrrolidino donor $\mathbf{5}$, which was inspired by the hypernucleophilic acylation 
catalyst 4-pyrrolidinopyridine. ${ }^{16}$ Despite the presence of a basic aniline, which potentially could inhibit thioglycoside activation, this donor (6) could still be activated under the applied conditions and was found to be the only one studied that was more reactive than the tetra-O-benzylated donor $\mathbf{1}$. Finally, as a confirmation of our method, a competition experiment between the 2-O-benzoylated donor 2 and the $p$ methoxybenzoylated donor 5 was performed (entry 6).

Given the variations in reactivity adhering to the expected order according to Hammett constants $\left(\sigma_{\mathrm{p}}\right)$, it was decided to see how well the measured data would appear in a Hammetttype plot. The reactivity of the listed donors was all evaluated identically in comparison to the same tetra-O-benzylated donor (1). The numbers (reactivity ratio, RR) listed in Table 1 are naturally not a ratio of rate constants because there is a "catching up effect" of the slower-reacting donor. As the difference in reactivity overall is small (within an order of magnitude), we will make the assumption that the following is a good approximation to be used for a linear free energy relationship because imperfections in rate constant determination would cancel out

$$
\begin{aligned}
\log \left(k_{\mathbf{X}} / k_{\mathbf{H}}\right) & =\log \left(k_{\mathbf{X}} / k_{\mathbf{2}}\right) \approx \log [\mathrm{RR}(\mathbf{X} / \mathbf{1}) / \mathrm{RR}(\mathbf{2} / \mathbf{1})] \\
\text { where } X & =\mathbf{2}, \mathbf{3}, \mathbf{4} \text { or } \mathbf{5}
\end{aligned}
$$

$\sigma_{\mathrm{p}}$ values were taken from a review by Taft and co-workers ${ }^{17}$ and $\mathrm{NMe}_{2}$ was used as an approximate value for the pyrrolidino group.

A good correlation was established $\left(R^{2}=0.979, N=5\right)$, with a slope of $\rho=0.6$ (Figure 2). The obtained straight line suggests a conserved reaction mechanism across the tested range of donors.

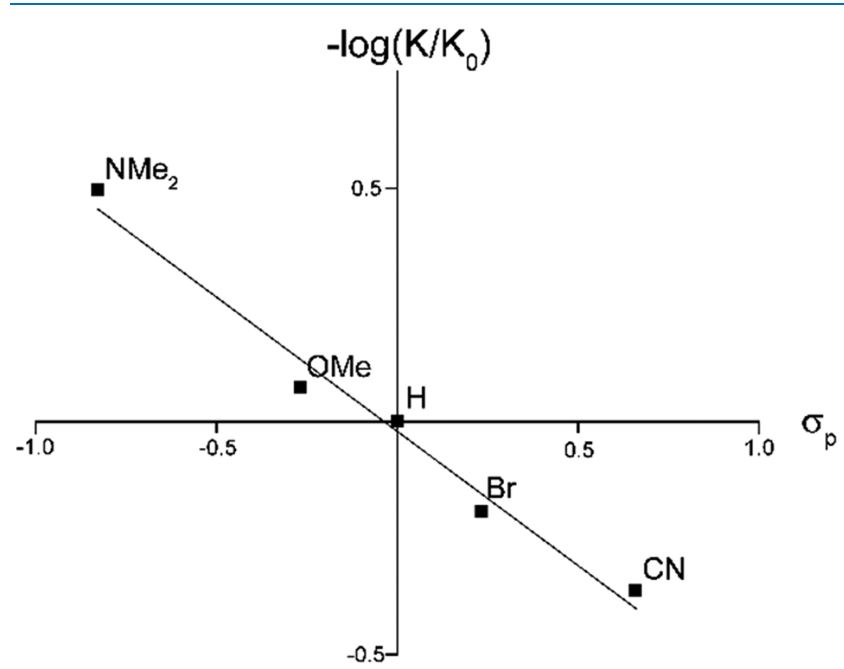

Figure 2. Correlation between reactivities of glycosyl donors and Hammett $\sigma_{\mathrm{p}}$ values.

The reactivity difference measured between donor $\mathbf{5}$ and $\mathbf{2}$ fits to that calculated based on the values obtained from the Hammett plot.

In a previous study by Huang and co-workers, where the para-substituent of phenyl thioglucosyl donors were studied, ${ }^{18}$ a slope of $\rho=3.4\left(R^{2}=0.99\right.$, acceptor: $\left.\mathrm{MeOH}\right)$ was found, which shows a much larger sensitivity to substituent variations compared to the present situation.
During a previous study, we separated the effects of anchimeric assistance, anomeric stereochemistry, and electron-withdrawing power of a $2-\mathrm{OBz}$ compared to a $2-\mathrm{OBn}$ under NIS/TfOH activation. ${ }^{8,9}$ Here, we found that the neighboring group acceleration (anchimeric effect) from a 2OBz substituent is inferior to the oppositely directed electronwithdrawing effect with respect to phenyl thioglucosides reactivity under NIS/TfOH activation. Still, given the significance of the anchimeric effect, it would be expected to be the major contributor to the reactivity variations found in the present study. Another possible cause of the observed variations in rate could simply be based on the differences in the inductive effects of the C-2 substituent.

To gain an insight into this, $p$-cyano- and p-methoxybenzoylated donors ( 3 and 4 , respectively) were competed against one another in both $\alpha$ - and $\beta$-series. A much greater difference in reactivity was measured for the $\beta$-anomers in accordance with the expected accelerating achimeric effect. The smaller difference, found for the analogous $\alpha$-configured donors (12 and 13), is a measure of the inductive difference between the two (Table 2).

\section{CONCLUSIONS}

We have studied the effect on the reactivity of para-substituted 2-O-benzoyls in glucosylation reactions with phenyl thioglucosides under NIS/TfOH activation and established the level of sensitivity to the electronic nature of the substituent. The study has given rise to a linear free-energy relationship, where Hammett $\sigma_{\mathrm{p}}$ constants were found to correlate well to the reactivity of the tested glucosyl donors.

The most reactive glycosyl donor explored in this study was found to have a 2-O-( $p$-pyrrolidino)-benzoyl substituent. This was prepared from the less reactive 2-O-( $p$-bromo)-benzoylated donor via Pd catalysis. Although the reactivity difference most likely is too small for chemoselective activation of the former donor type, the chemistry presented in the present study could possibly be used in combination with other effects for fine-tuning the reactivity, which would allow for rapid oligosaccharide assembly.

\section{EXPERIMENTAL SECTION}

General Methods. All the reagents were used as purchased without further purification. Dry solvents were taken from a solvent purification system. Importantly, high-quality NIS was used (Chempur (004499), N-iodosuccinimide/98\%+). Glassware used for water-sensitive reactions were dried for $12 \mathrm{~h}$ at $120{ }^{\circ} \mathrm{C}$ before use. Columns for chromatography were packed with silica gel 60 (230-400 mesh) as the stationary phase. The thin-layer chromatography plates were visualized by $10 \%$ $\mathrm{H}_{2} \mathrm{SO}_{4}$ in $\mathrm{EtOH}$ and heating until spots appeared. ${ }^{1} \mathrm{H}$ NMR and ${ }^{13} \mathrm{C}$ NMR spectra were recorded on a $400 \mathrm{MHz}$ spectrometer. Chemical shifts $(\delta)$ are reported in ppm relative to the residual solvent signal. High-resolution mass spectral (HRMS) data were obtained on an electrospray (ES) mass spectrometer analyzing time of flight.

General Procedure for Glycosylations. Glycosyl donor $(0.10 \mathrm{mmol})$ and glycosyl acceptor $(0.15 \mathrm{mmol})$ were dissolved in $\mathrm{CH}_{2} \mathrm{Cl}_{2}(2 \mathrm{~mL})$ before freshly activated molecular sieves $(3 \AA, 100 \mathrm{mg}$ ) were added. The mixture was stirred under argon for $1 \mathrm{~h}$ at ambient temperature and then cooled to $-78{ }^{\circ} \mathrm{C}$ using a dry ice/acetone bath. At this temperature, first NIS $(0.11 \mathrm{mmol})$ and then $\mathrm{TfOH}(0.1 \mathrm{~mL}$ of a $0.1 \mathrm{M}$ solution 
Table 2. Competition Experiments

$\begin{array}{lll}\text { Entry } & \text { Reactivity Ratio, RR } \\ \text { (reciprocal ratio) }\end{array}$

of $\mathrm{TfOH}$ in $\mathrm{CH}_{2} \mathrm{Cl}_{2}$ ) were added. The pieces of dry ice were then removed from the cold bath, allowing the reaction vessel to reach $0{ }^{\circ} \mathrm{C}$ over approximately $3 \mathrm{~h}$. At this temperature, the solids were filtered off and the filtrate was washed with $10 \%$ $\mathrm{Na}_{2} \mathrm{~S}_{2} \mathrm{O}_{3}$ in water. The organic phase was separated, dried over $\mathrm{MgSO}_{4}$, and concentrated under reduced pressure, and the residue purified by flash column chromatography on a silica gel to afford the corresponding glycoside. Anomeric ratios were measured by comparing the integral intensities of $\mathrm{H}-1$ and $\mathrm{C}-1$ from ${ }^{1} \mathrm{H}$ NMR and ${ }^{13} \mathrm{C}$ NMR spectra of crude reaction mixtures.

Competition Experiments. The competing glycosyl donors $\left(0.10 \mathrm{mmol}\right.$ each) were first dissolved in $\mathrm{CDCl}_{3}$ (1 $\mathrm{mL})$ and their ratio checked to be $1.0: 1.0$ by ${ }^{1} \mathrm{H}$ NMR and ${ }^{13} \mathrm{C}$ NMR. Then, the solvent was removed in reduced pressure and the mixture redissolved in dry $\mathrm{CH}_{2} \mathrm{Cl}_{2}(2 \mathrm{~mL})$ before Lmenthol $(0.5 \mathrm{mmol})$ and freshly activated molecular sieves (3 $\AA$, $100 \mathrm{mg}$ ) were added. The mixture was stirred at ambient temperature under an atmosphere of argon for $1 \mathrm{~h}$ before cooling to $-78{ }^{\circ} \mathrm{C}$ in an dry ice/acetone bath. At this temperature, first NIS $(0.10 \mathrm{mmol})$ and then $\mathrm{TfOH}(0.1 \mathrm{~mL}$ of a $0.1 \mathrm{M}$ solution of $\mathrm{TfOH}$ in $\mathrm{CH}_{2} \mathrm{Cl}_{2}$ ) were added. The pieces of dry ice were then removed, allowing the temperature to reach $0{ }^{\circ} \mathrm{C}$ (approximately $3 \mathrm{~h}$ ). At this time, all the solids were filtered off and the filtrate washed with aqueous $\mathrm{Na}_{2} \mathrm{~S}_{2} \mathrm{O}_{2}$ solution $(10 \%)$. The organic phase was then separated, dried over $\mathrm{MgSO}_{4}$, and concentrated. Next, the crude mixture was dissolved in $\mathrm{CDCl}_{3}(1 \mathrm{~mL})$ and ${ }^{1} \mathrm{H}$ NMR and ${ }^{13} \mathrm{C}$ NMR spectra were recorded. The ratio of unreacted donors were measured by comparing the integral intensities of anomeric protons and anomeric carbons from ${ }^{1} \mathrm{H}$ NMR and ${ }^{13} \mathrm{C}$ NMR spectra of crude reaction mixtures.

Phenyl 3,4,6-Tri-O-benzyl-2-O-( $p$-bromobenzoyl)-1thio- $\boldsymbol{\beta}$-D-glucopyranoside (3). A suspension of phenyl 3,4,6-tri- $O$-benzyl-2- $O$-acetyl-1-thio- $\beta$-D-glucopyranoside ${ }^{8}$ $(1.29 \mathrm{~g}, 2.15 \mathrm{mmol})$ in $\mathrm{MeOH}$ was heated to $40{ }^{\circ} \mathrm{C}$ to improve the solubility and sodium methoxide solution (25 wt \% in $\mathrm{MeOH}$ ) was added until a $\mathrm{pH}$ value of approximately 10 was reached. The reaction mixture was stirred for $5 \mathrm{~h}$ and then neutralized with DOWEX acidic ion exchanger. The solid was filtered off and filtrate concentrated in vacuo, leaving the crude 2-hydroxyl glycoside 7 .
The 2-hydroxyl glycoside $\mathbf{1}$ was dissolved in anhydrous $\mathrm{CH}_{2} \mathrm{Cl}_{2}(20 \mathrm{~mL})$ and DMAP (132 mg, $1.07 \mathrm{mmol}, 0.5$ equiv.), $\mathrm{Et}_{3} \mathrm{~N}$ (1.49 mL, $10.7 \mathrm{mmol}, 5$ equiv.), and 4-bromobenzoyl chloride ( $1.89 \mathrm{~g}$, $8.59 \mathrm{mmol}, 4$ equiv.) were added. The orange slurry was stirred at room temperature (rt) for $18 \mathrm{~h}$ under $\mathrm{N}_{2}$ atmosphere before being quenched by the addition of DMAPA $^{10}$ (1.08 mL, $8.54 \mathrm{mmol}, 4$ equiv.). The reaction mixture was stirred with DMAPA for $10 \mathrm{~min}$ before washing with aq. $1 \mathrm{M}$ aq. $\mathrm{HCl}$ (three times), sat. aq. $\mathrm{NaHCO}_{3}$, and brine. The organic phase was dried over $\mathrm{MgSO}_{4}$, filtered, and concentrated in vacuo. Recrystallization of the resulting residue from EtOAc/pentane yielded the product $(1.33 \mathrm{~g}, 1.83 \mathrm{mmol})$ as a white flocculent solid in $85 \%$ yield over two steps. $R_{\mathrm{f}}$ (EtOAc/pentane 3:1) 0.67. $[\alpha]_{\mathrm{D}}{ }^{295 \mathrm{~K}} 43.2\left(\right.$ c 1.0, $\left.\mathrm{CHCl}_{3}\right) . M_{\mathrm{p}}$ (uncorr.) $132.0-134.0{ }^{\circ} \mathrm{C} .{ }^{1} \mathrm{H}$ NMR $\left(400 \mathrm{MHz}, \mathrm{CDCl}_{3}\right) \delta_{\mathrm{H}}$ 7.77 (d, J $8.6 \mathrm{~Hz}, 2 \mathrm{H}, \operatorname{ArH}), 7.49$ (d, J $8.6 \mathrm{~Hz}, 2 \mathrm{H}, \operatorname{ArH}$ ), 7.41-7.35 (m, 2H, ArH), 7.29-7.08 (m, 13H, ArH), 7.076.98 (m, 5H, ArH), 5.16 (dd, J 9.9, 9.0 Hz, 1H, H2), 4.73 (d, J $10.9 \mathrm{~Hz}, 1 \mathrm{H}, \mathrm{CHHPh}$ ), 4.67 (d, J $10.0 \mathrm{~Hz}, 1 \mathrm{H}, \mathrm{H1}$ ), 4.65 (d, J $11.1 \mathrm{~Hz}, 1 \mathrm{H}, \mathrm{CHHPh}), 4.54$ (d, J $11.9 \mathrm{~Hz}, 1 \mathrm{H} \mathrm{CHHPh)} \mathrm{4.54-}$ $4.49(\mathrm{~m}, 2 \mathrm{H}, 2 \times \mathrm{CHHPh}), 4.48(\mathrm{~d}, J 11.9 \mathrm{~Hz}, 1 \mathrm{H} \mathrm{CHHPh})$, 3.74 (dd, J 11.0, $1.8 \mathrm{~Hz}, 1 \mathrm{H}, \mathrm{H} 6 \mathrm{a}), 3.73$ (t, J $8.8 \mathrm{~Hz}, 1 \mathrm{H}, \mathrm{H} 3$ ), 3.70-3.64 (m, 1H, H6b), $3.66(\mathrm{t}, J 9.2 \mathrm{~Hz}, 1 \mathrm{H}, \mathrm{H} 4), 3.52$ (ddd, J 9.4, 4.7, $1.8 \mathrm{~Hz}, 1 \mathrm{H}, \mathrm{H} 5) .{ }^{13} \mathrm{C} \mathrm{NMR}(101 \mathrm{MHz}$, $\left.\mathrm{CDCl}_{3}\right) \delta_{\mathrm{C}} 164.6(\mathrm{C}=\mathrm{O}), 138.3,138.0,137.7,132.9,132.6$, 131.9, 131.5, 129.0-127.7 (Ar), 86.2 (C1), 84.3 (C3), 79.6 (C5), $78.0(\mathrm{C} 4), 75.4\left(\mathrm{CH}_{2} \mathrm{Ph}\right), 75.3\left(\mathrm{CH}_{2} \mathrm{Ph}\right), 73.6\left(\mathrm{CH}_{2} \mathrm{Ph}\right)$, 72.7 (C2), 69.0 (C6). HRMS (ES): calcd for $\mathrm{C}_{40} \mathrm{H}_{37}{ }^{79} \mathrm{BrO}_{6} \mathrm{SNH}_{4}^{+} 742.1832$; found 742.1816 .

Phenyl 3,4,6-Tri-O-benzyl-2-O-( $p$-cyanobenzoyl)-1thio- $\boldsymbol{\beta}$-D-glucopyranoside (4). To a screw-top vial equipped with a magnetic stir bar was added phenyl 3,4,6-tri-O-benzyl-2$O$-( $p$-bromobenzoyl)-1-thio- $\beta$-D-glucopyranoside $3(73 \mathrm{mg}$, $0.10 \mathrm{mmol}, 1$ equiv. $), \mathrm{K}_{4}\left[\mathrm{Fe}(\mathrm{CN})_{6}\right] \cdot 3 \mathrm{H}_{2} \mathrm{O}$ (21 mg, 0.05 mmol, 0.5 equiv.), $t$ BuXPhos Pd G3 (4 mg, $5 \mathrm{~mol} \%$ ), and $t$ BuXPhos $(2 \mathrm{mg}, 5 \mathrm{~mol} \%)$. After sealing with a Teflon-lined screw-cap septum, the vessel was evacuated and backfilled with argon (this process was repeated for a total of three times). Dioxane $(0.3 \mathrm{~mL})$ and $0.05 \mathrm{M} \mathrm{KOAc}$ in degassed water $(0.3$ $\mathrm{mL}$ ) were added to the reaction vial via a syringe. The vial was placed in an oil bath preheated to $100{ }^{\circ} \mathrm{C}$ and stirred for $1.5 \mathrm{~h}$ at maximum stirring $(1500 \mathrm{rpm})$. The reaction mixture was 
then cooled to rt and transferred to a separatory funnel using EtOAc and brine. The blue aqueous layer was further extracted with EtOAc (twice). The combined organic layers were dried over $\mathrm{MgSO}_{4}$, filtered, and concentrated in vacuo. The residue was purified by flash column chromatography (pentane/ EtOAc $7: 1)$ to yield the product $(64 \mathrm{mg}, 0.095 \mathrm{mmol})$ as a white crystalline solid in $95 \%$ yield. $R_{\mathrm{f}}$ (EtOAc/pentane $3: 1$ ) 0.37. $[\alpha]_{\mathrm{D}}{ }^{295 \mathrm{~K}}+41.6$ (c 1.0, $\left.\mathrm{CHCl}_{3}\right) . \mathrm{M}_{\mathrm{p}}$ (uncorr.) 116.1$117.7{ }^{\circ} \mathrm{C} .{ }^{1} \mathrm{H}$ NMR $\left(400 \mathrm{MHz}, \mathrm{CDCl}_{3}\right) \delta_{\mathrm{H}} 8.22(\mathrm{~d}, J 8.5 \mathrm{~Hz}$, $2 \mathrm{H}), 7.87$ (d, J $8.5 \mathrm{~Hz}, 2 \mathrm{H}), 7.68-7.61(\mathrm{~m}, 2 \mathrm{H}), 7.57-7.35$ (m, 13H), 7.30-7.22 (m, 5H), $5.45(\mathrm{dd}, J 10.0,9.0 \mathrm{~Hz}, 1 \mathrm{H}$, H2), 5.01 (d, J $10.9 \mathrm{~Hz}, 1 \mathrm{H}, \mathrm{CHHPh}), 4.97$ (d, J $11.5 \mathrm{~Hz}, 1 \mathrm{H}$, CHHPh), 4.96 (d, J $10.0 \mathrm{~Hz}, 1 \mathrm{H}, \mathrm{H1}), 4.81$ (d, J $12.0 \mathrm{~Hz}, 1 \mathrm{H}$, CHHPh), 4.80 (d, J $12.4 \mathrm{~Hz}, 1 \mathrm{H}, \mathrm{CHHPh}$ ), 4.78 (d, J $12.4 \mathrm{~Hz}$, $1 \mathrm{H}, \mathrm{CHHPh}$ ), 4.75 (d, J $10.9 \mathrm{~Hz}, 1 \mathrm{H}, \mathrm{CHHPh}), 4.06-3.92$ (m, 2H, H3, H6b), 4.02 (dd, J 11.5, $2.4 \mathrm{~Hz}, 1 \mathrm{H}, \mathrm{H6a}), 3.96(\mathrm{t}$, J $9.3 \mathrm{~Hz}, 1 \mathrm{H}, \mathrm{H} 4$ ), 3.81 (ddd, J 9.4, $4.5,1.8 \mathrm{~Hz}, 1 \mathrm{H}, \mathrm{H} 5) .{ }^{13} \mathrm{C}$ NMR $\left(101 \mathrm{MHz}, \mathrm{CDCl}_{3}\right) \delta_{\mathrm{C}} 163.7(\mathrm{C}=\mathrm{O}), 138.2,137.9$, 137.7, 133.6, 132.6, 132.5, 132.3, 130.3, 129.0-127.8 (Ar), $118.1(\mathrm{CN}), 116.6(\mathrm{ArC}-\mathrm{CN}), 85.9$ (C1), 84.1 (C3), 79.6 (C5), $78.1(\mathrm{C} 4), 75.4\left(\mathrm{CH}_{2} \mathrm{Ph}\right), 75.2\left(\mathrm{CH}_{2} \mathrm{Ph}\right), 73.6\left(\mathrm{CH}_{2} \mathrm{Ph}\right)$, 73.0 (C2), 68.9 (C6). HRMS (ES): calcd for $\mathrm{C}_{41} \mathrm{H}_{37} \mathrm{NO}_{6} \mathrm{SNH}_{4}^{+}$689.2680; found 689.2680.

Phenyl 3,4,6-Tri-O-benzyl-2-O-( $p$-methoxybenzoyl)1-thio- $\boldsymbol{\beta}$-D-glucopyranoside (5). To a screw-top vial (A) equipped with a magnetic stir bar was added phenyl 3,4,6-tri$O$-benzyl-2- $O$-( $p$-bromobenzoyl $)$-1-thio- $\beta$-D-glucopyranoside (73 mg, 0.10 mmol, 1 equiv.), $\mathrm{Cs}_{2} \mathrm{CO}_{3}$ (46 mg, $0.14 \mathrm{mmol}, 1.4$ equiv.), and $t$ BuBrettPhos (2.4 mg, $0.005 \mathrm{mmol}, 5 \mathrm{~mol} \%$ ). The vial was sealed with a Teflon-lined screw-cap septum, the vessel was evacuated and backfilled with argon (this process was repeated for a total of three cycles), and $\mathrm{MeOH}(16 \mu \mathrm{L}$, $0.5 \mathrm{mmol}, 5$ equiv.) was added via a syringe. To another screwtop vial (B) equipped with a magnetic stir bar was added $t$ BuBrettPhos Pd G3 (4.2 mg, $0.005 \mathrm{mmol}, 5 \mathrm{~mol} \%$ ) and the vial (B) was evacuated and backfilled with argon (repeated for a total of three cycles). Anhydrous 1,4-dioxane (0.5 mL) was added to vial $\mathbf{B}$ via a syringe and the mixture in vial $\mathbf{B}$ was stirred at $\mathrm{rt}$ for $1 \mathrm{~min}$ to form a homogeneous solution. The precatalyst solution was transferred into vial $\mathbf{B}$ via a syringe. The resulting mixture in tube $\mathbf{A}$ was stirred at $\mathrm{rt}$ for $20 \mathrm{~h}$. The reaction mixture was diluted with EtOAc and concentrated in vacuo. The residue was purified by flash column chromatography (pentane/EtOAc 15:1) to afford the product $(38 \mathrm{mg}$, $0.058 \mathrm{mmol}$ ) as a white solid in $57 \%$ yield. Unreacted starting material was isolated in $33 \%$ recovery $(24 \mathrm{mg}, 0.033 \mathrm{mmol})$. The corrected yield was calculated to be $84 \%$. $R_{\mathrm{f}}$ (pentane/ EtOAc 4:1) 0.38, $[\alpha]_{\mathrm{D}}{ }^{295 \mathrm{~K}}+44.6\left(c 1.0, \mathrm{CHCl}_{3}\right)$, lit. 45 (c 0.9, $\left.\mathrm{CHCl}_{3}\right) .{ }^{19} \mathrm{M}_{\mathrm{p}}$ (uncorr.) 95.0-95.9 ${ }^{\circ} \mathrm{C}$, lit. $110-111{ }^{\circ} \mathrm{C}$ (ether/petrol) ${ }^{\mathrm{v}} .{ }^{1} \mathrm{H} \mathrm{NMR}\left(400 \mathrm{MHz}, \mathrm{CDCl}_{3}\right) \delta_{\mathrm{H}} 8.06(\mathrm{~d}, J 8.9$ $\mathrm{Hz}, 2 \mathrm{H}, \mathrm{ArH}$ ), 7.53 (dd, J 7.6, $1.8 \mathrm{~Hz}, 2 \mathrm{H}, \mathrm{ArH}$ ), 7.41-7.13 $(\mathrm{m}, 18 \mathrm{H}, \mathrm{ArH}), 6.97$ (d, J $8.9 \mathrm{~Hz}, 1 \mathrm{H}, \mathrm{ArH}), 5.32(\mathrm{t}, J 9.5 \mathrm{~Hz}$, $1 \mathrm{H}, \mathrm{H} 2), 4.86$ (d, J $10.9 \mathrm{~Hz}, 1 \mathrm{H}, \mathrm{CHHPh}), 4.82(\mathrm{~d}, J 10.1 \mathrm{~Hz}$, 1H, H1), 4.76 (d, J $10.9 \mathrm{~Hz}, 1 \mathrm{H}, \mathrm{CHHPh}), 4.69$ (d, J $11.0 \mathrm{~Hz}$, 1H, CHHPh), 4.66 (d, J $11.8 \mathrm{~Hz}, 1 \mathrm{H}, \mathrm{CHHPh}$ ), 4.63 (d, J 11.3 $\mathrm{Hz}, 1 \mathrm{H}, \mathrm{CH} H \mathrm{Ph}$ ), 4.60 (d, J 12.1 Hz, 1H, CHHPh), 3.91 (s, $3 \mathrm{H}, \mathrm{OCH}_{3}$ ), 3.89-3.83 (m, 2H, H3, H6a), 3.79 (dd, J 10.4, $4.5 \mathrm{~Hz}, 1 \mathrm{H}, \mathrm{H} 6 \mathrm{~b}$ ), 3.83-3.74 (m, 1H, H4), 3.66 (ddd, J 9.6, 4.7, $1.5 \mathrm{~Hz}, 1 \mathrm{H}, \mathrm{H} 5) .{ }^{13} \mathrm{C} \mathrm{NMR}\left(101 \mathrm{MHz}, \mathrm{CDCl}_{3}\right) \delta_{\mathrm{C}} 164.9$ $(\mathrm{C}=\mathrm{O}), 163.6\left(\mathrm{ArC}-\mathrm{OCH}_{3}\right), 138.3,138.0,137.8,133.2$, 132.4, 132.0, 128.8-127.6, 122.3, 113.7 (Ar), 86.3 (C1), 84.4 (C3), 79.5 (C5), 77.8 (C4), $75.4\left(\mathrm{CH}_{2} \mathrm{Ph}\right), 75.1\left(\mathrm{CH}_{2} \mathrm{Ph}\right)$, $73.5\left(\mathrm{CH}_{2} \mathrm{Ph}\right), 72.3(\mathrm{C} 2), 69.0$ (C6), $55.5\left(\mathrm{OCH}_{3}\right)$. HRMS
(ES): calcd for $\mathrm{C}_{41} \mathrm{H}_{40} \mathrm{O}_{7} \mathrm{SNa}^{+}$699.2387; found 699.2399. Spectral values were in accordance with the previously reported data. ${ }^{19}$

Phenyl 3,4,6-Tri-O-benzyl-2-O-(p-pyrrolidinobenzoyl)-1-thio- $\beta$-D-glucopyranoside (6). To a screw-top vial equipped with a magnetic stir bar was added phenyl 3,4,6-tri$O$-benzyl-2-O-( $p$-bromobenzoyl)-1-thio- $\beta$-D-glucopyranoside 3 (223 mg, $0.31 \mathrm{mmol}, 1$ equiv.), $\mathrm{Cs}_{2} \mathrm{CO}_{3}(120 \mathrm{mg}, 0.37 \mathrm{mmol}$, 1.2 equiv.), RuPhos Pd G3 (12 mg, $5 \mathrm{~mol} \%$ ), and RuPhos (7 $\mathrm{mg}, 5 \mathrm{~mol} \%)$. After sealing with a Teflon-lined screw-cap septum, the vessel was evacuated and backfilled with argon (this process was repeated for a total of three cycles). Pyrrolidine (31 $\mu \mathrm{L}, 0.37 \mathrm{mmol}, 1.2$ equiv.) and $t \mathrm{BuOH}$ (degassed, $1 \mathrm{~mL}$ ) were added to the reaction vial via syringes. The vial was placed in an oil bath preheated to $85{ }^{\circ} \mathrm{C}$ and vigorously stirred $(1000 \mathrm{rpm})$ for $18 \mathrm{~h}$. The reaction mixture was then cooled to rt, diluted with EtOAc, and washed with $\mathrm{H}_{2} \mathrm{O}$. The organic layer was dried over $\mathrm{Na}_{2} \mathrm{SO}_{4}$, filtered, and concentrated in vacuo. The residue was purified by flash column chromatography (pentane/EtOAc 10:1 to 5:1) yielding the product $(145 \mathrm{mg}, 0.20 \mathrm{mmol})$ as a white solid in $66 \%$ yield. $R_{\mathrm{f}}$ (pentane/EtOAc $\left.3: 1\right) 0.44 .[\alpha]_{\mathrm{D}}{ }^{295 \mathrm{~K}}+68.3(c$ 1.0, $\left.\mathrm{CHCl}_{3}\right) \cdot M_{\mathrm{p}}$ (uncorr.) $148.0-148.9{ }^{\circ} \mathrm{C} .{ }^{1} \mathrm{H}$ NMR (400 $\left.\mathrm{MHz}, \mathrm{CDCl}_{3}\right) \delta_{\mathrm{H}} 7.88(\mathrm{~d}, J 8.9 \mathrm{~Hz}, 2 \mathrm{H}, \mathrm{ArH}), 7.44-7.37(\mathrm{~m}$, 2H, ArH), 7.29-7.04 (m, 18H, ArH), 6.45 (d, J $8.9 \mathrm{~Hz}, 2 \mathrm{H}$, $\operatorname{ArH}), 5.21(\mathrm{t}, J 9.5 \mathrm{~Hz}, 1 \mathrm{H}, \mathrm{H} 2), 4.74(\mathrm{~d}, J 11.2 \mathrm{~Hz}, 1 \mathrm{H}$, CHHPh), 4.71 (d, J $10.2 \mathrm{~Hz}, 1 \mathrm{H}, \mathrm{H1}), 4.63$ (d, J $10.7 \mathrm{~Hz}, 1 \mathrm{H}$, $\mathrm{CHHPh}$ ), 4.59 (d, J $10.7 \mathrm{~Hz}, 1 \mathrm{H}, \mathrm{CHHPh}), 4.53$ (d, J $12.0 \mathrm{~Hz}$, $1 \mathrm{H}, \mathrm{CHHPh}$ ), 4.48 (d, J $12.0 \mathrm{~Hz}, 1 \mathrm{H}, \mathrm{CHHPh}), 3.78$ (t, J 8.2 $\mathrm{Hz}, 1 \mathrm{H}, \mathrm{H} 3$ ), 3.77-3.72 (m, 1H, H6a), 3.70-3.59 (m, 2H, H4, H6b), 3.54 (ddd, J 9.8, 4.9, $1.5 \mathrm{~Hz}, 1 \mathrm{H}, \mathrm{H} 5$ ), 3.33-3.25 $\left(\mathrm{m}, 4 \mathrm{H}, 2 \times \mathrm{N}-\mathrm{CH}_{2}\right), 1.99-1.92\left(\mathrm{~m}, 4 \mathrm{H}, 2 \times \mathrm{CH}_{2}\right) \cdot{ }^{13} \mathrm{C}$ NMR $\left(101 \mathrm{MHz}, \mathrm{CDCl}_{3}\right) \delta 165.6(\mathrm{C}=\mathrm{O}), 151.1,138.3$, $138.1,137.9,133.6,132.3,131.9,128.7-127.5,115.9,110.7$ (Ar), 86.5 (H1), 84.7 (H3), 79.4 (H5), 77.7 (H4), 75.3 $\left(\mathrm{CH}_{2} \mathrm{Ph}\right), 75.1\left(\mathrm{CH}_{2} \mathrm{Ph}\right), 73.5\left(\mathrm{CH}_{2} \mathrm{Ph}\right), 71.9(\mathrm{H} 2), 69.2$ (H6), $47.6\left(\mathrm{~N}-\mathrm{CH}_{2}\right), 25.5\left(\mathrm{~N}-\mathrm{CH}_{2}-\mathrm{CH}_{2}\right)$. HRMS (ES): calcd for $\mathrm{C}_{44} \mathrm{H}_{45} \mathrm{NO}_{6} \mathrm{SH}^{+} 716.3040$; found 716.3045 .

L-Menthyl 3,4,6-Tri-O-benzyl-2-O-(p-bromobenzoyl)$\boldsymbol{\beta}$-D-glucopyranoside (8). White crystalline solid, $77 \mathrm{mg}$, quantitative yield.

$R_{\mathrm{f}}$ (pentane/EtOAc 4:1) 0.60. $[\alpha]_{\mathrm{D}}{ }^{295 \mathrm{~K}}-12.2$ (c 1.0 , $\left.\mathrm{CHCl}_{3}\right) . \quad M_{\mathrm{p}}$ (uncorr.) 132.0-134.0 ${ }^{\circ} \mathrm{C} .{ }^{1} \mathrm{H}$ NMR (400 $\left.\mathrm{MHz}, \mathrm{CDCl}_{3}\right) \delta_{\mathrm{H}} 7.98(\mathrm{~d}, J 8.6 \mathrm{~Hz}, 2 \mathrm{H}, \mathrm{ArH}), 7.70$ (d, J 8.6 $\mathrm{Hz}, 2 \mathrm{H}, \mathrm{ArH}$ ), 7.50-7.36 (m, 10H, ArH), 7.30-7.22 (m, 5H, $\mathrm{ArH})$, 5.36-5.28 (m, 1H, H2), 4.97 (d, J $10.8 \mathrm{~Hz}, 1 \mathrm{H}$, $\mathrm{CHHPh}), 4.89$ (d, J $11.4 \mathrm{~Hz}, 1 \mathrm{H}, \mathrm{CHHPh}), 4.78(\mathrm{~d}, J 11.9 \mathrm{~Hz}$, $1 \mathrm{H}, \mathrm{CHHPh}$ ), 4.77 (d, J $10.8 \mathrm{~Hz}, 1 \mathrm{H}, \mathrm{CHHPh}), 4.76$ (d, J 11.4 $\mathrm{Hz}, 1 \mathrm{H}, \mathrm{CHHPh}), 4.71$ (d, J $12.3 \mathrm{~Hz}, 1 \mathrm{H}, \mathrm{CHHPh}$ ), 4.68 (d, J $8.1 \mathrm{~Hz}, 1 \mathrm{H}, \mathrm{H} 1), 3.94-3.85(\mathrm{~m}, 4 \mathrm{H}, \mathrm{H} 3, \mathrm{H} 4, \mathrm{H} 6 \mathrm{a}, \mathrm{H} 6 \mathrm{~b})$, 3.67-3.60 (m, 1H, H5), $3.52(\mathrm{dt}, J 10.6,4.2 \mathrm{~Hz}, 1 \mathrm{H}, \mathrm{OCH})$, 2.43 (dsep, J 6.9, $\left.2.4 \mathrm{~Hz}, 1 \mathrm{H}, \mathrm{CH}\left(\mathrm{CH}_{3}\right)_{2}\right), 1.98(\mathrm{~d}, J 12.2 \mathrm{~Hz}$, $1 \mathrm{H}), 1.74-1.66(\mathrm{~m}, 2 \mathrm{H}), 1.46-1.35(\mathrm{~m}, 2 \mathrm{H}), 1.31-1.22(\mathrm{~m}$, $1 \mathrm{H}), 1.12-1.02(\mathrm{~m}, 1 \mathrm{H}), 0.99\left(\mathrm{~d}, J 7.1 \mathrm{~Hz}, 3 \mathrm{H}, \mathrm{CH}_{3}\right), 0.91(\mathrm{~d}$, J $\left.6.9 \mathrm{~Hz}, 3 \mathrm{H}, \mathrm{CH}_{3}\right), 0.89$ (d, J $\left.6.5 \mathrm{~Hz}, 3 \mathrm{H}, \mathrm{CH}_{3}\right), 0.78-0.67$ $(\mathrm{m}, 1 \mathrm{H}) .{ }^{13} \mathrm{C}$ NMR $\left(101 \mathrm{MHz}, \mathrm{CDCl}_{3}\right) \delta_{\mathrm{C}} 164.5(\mathrm{C}=\mathrm{O})$, 138.3 , 138.0, 137.9, 131.6, 131.3, 129.2, 128.5-127.6 (Ar), 99.0 (C1), 82.8 (C3/C4), $78.6(\mathrm{OCH}), 78.23$ (C4/C3), 75.3 (C5), $75.1\left(\mathrm{CH}_{2} \mathrm{Ph}\right), 74.9\left(\mathrm{CH}_{2} \mathrm{Ph}\right), 74.2(\mathrm{C} 2), 73.8\left(\mathrm{CH}_{2} \mathrm{Ph}\right)$, 69.1 (C6), 47.4, $41.0\left(\mathrm{CH}_{2}\right), 34.2\left(\mathrm{CH}_{2}\right), 31.3\left(\mathrm{CH}\left(\mathrm{CH}_{3}\right)_{2}\right)$, $25.0\left(\mathrm{CH}_{2}\right), 23.0,22.1\left(\mathrm{CH}_{3}\right), 21.0\left(\mathrm{CH}_{3}\right), 15.8\left(\mathrm{CH}_{3}\right)$. HRMS (ES): calcd for $\mathrm{C}_{44} \mathrm{H}_{54}{ }^{79} \mathrm{BrO}_{7} \mathrm{NH}_{4}^{+} 788.3156$; found 788.3152 . 
L-Menthyl 3,4,6-Tri-O-benzyl-2-O-(p-cyanobenzoyl)$\beta$-D-glucopyranoside (9). White crystalline solid, $62 \mathrm{mg}$, $86 \%$.

$R_{\mathrm{f}}$ (pentane/EtOAc 4:1) 0.63. $[\alpha]_{\mathrm{D}}{ }^{295 \mathrm{~K}}-13.2$ (c 1.0, $\mathrm{CHCl}_{3}$ ). $\mathrm{M}_{\mathrm{p}}$ (uncorr.) 99.5-101.9 ${ }^{\circ} \mathrm{C}$. ${ }^{1} \mathrm{H}$ NMR (400 MHz, $\left.\mathrm{CDCl}_{3}\right) \delta_{\mathrm{H}} 8.04(\mathrm{~d}, J 8.3 \mathrm{~Hz}, 2 \mathrm{H}, \mathrm{ArH}), 7.72(\mathrm{~d}, J 8.3 \mathrm{~Hz}, 2 \mathrm{H}$, $\mathrm{ArH}), 7.40-7.22(\mathrm{~m}, 10 \mathrm{H}, \mathrm{ArH}), 7.17-7.05$ (m, 5H, $\mathrm{ArH})$, $5.19(\mathrm{t}, J 8.4 \mathrm{~Hz}, 1 \mathrm{H}, \mathrm{H} 2), 4.85$ (d, J $10.8 \mathrm{~Hz}, 1 \mathrm{H}, \mathrm{CHHPh})$, 4.80 (d, J $11.5 \mathrm{~Hz}, 1 \mathrm{H}, \mathrm{CHHPh}$ ), 4.67 (d, J $10.9 \mathrm{~Hz}, 1 \mathrm{H}$, CHHPh), 4.66 (d, J $12.3 \mathrm{~Hz}, 1 \mathrm{H}, \mathrm{CHHPh}$ ), 4.62 (d, J $10.7 \mathrm{~Hz}$, 1H, CHHPh), 4.59 (d, J $11.9 \mathrm{~Hz}, 1 \mathrm{H}, \mathrm{CHHPh}), 4.55$ (d, J 8.0 $\mathrm{Hz}, 1 \mathrm{H}, \mathrm{H1}), 3.55-3.49$ (m, 1H), 3.83-2.72 (m, 4H, H3, H4, H6a, H6b), 3.56-3.48 (m, 1H, H5), 3.40 (dt, J 10.6, $4.2 \mathrm{~Hz}$, $1 \mathrm{H}, \mathrm{OCH}$ ), 2.30 (dsep, J 6.8, $\left.2.1 \mathrm{~Hz}, 1 \mathrm{H}, \mathrm{CH}\left(\mathrm{CH}_{3}\right)_{2}\right), 1.83$ (d, J $12.2 \mathrm{~Hz}, 1 \mathrm{H}), 1.62-1.53(\mathrm{~m}, 2 \mathrm{H}), 1.35-1.20(\mathrm{~m}, 2 \mathrm{H})$, $1.17-1.08(\mathrm{~m}, 1 \mathrm{H}), 0.97-0.64(\mathrm{~m}, 1 \mathrm{H}), 0.86(\mathrm{~d}, J 7.1 \mathrm{~Hz}, 3 \mathrm{H}$, $\mathrm{CH}_{3}$ ), 0.78 (d, J $\left.6.8 \mathrm{~Hz}, 3 \mathrm{H}, \mathrm{CH}_{3}\right), 0.74$ (d, J $6.5 \mathrm{~Hz}, 3 \mathrm{H}$, $\left.\mathrm{CH}_{3}\right), 0.55(\mathrm{q}, J 11.7 \mathrm{~Hz}, 1 \mathrm{H}) \cdot{ }^{13} \mathrm{C}$ NMR $\left(101 \mathrm{MHz}, \mathrm{CDCl}_{3}\right)$ $\delta_{\mathrm{C}} 163.5(\mathrm{C}=\mathrm{O}), 138.2,137.9,137.9,134.0,132.1,130.2$, 128.5-127.6 (Ar), $118.1(\mathrm{CN}), 116.3(\mathrm{Ar}-\mathrm{CN}), 98.8(\mathrm{C} 1)$, 82.6 (C3/C4), $78.5(\mathrm{OCH}), 78.4$ (C4/C3), 75.2 (C5), 75.1 $\left(\mathrm{CH}_{2} \mathrm{Ph}\right), 74.9\left(\mathrm{CH}_{2} \mathrm{Ph}\right), 74.5(\mathrm{C} 2), 73.8\left(\mathrm{CH}_{2} \mathrm{Ph}\right), 69.0(\mathrm{C} 6)$, 47.4, 41.1 $\left(\mathrm{CH}_{2}\right), 34.1\left(\mathrm{CH}_{2}\right), 31.3,25.0\left(\mathrm{CH}\left(\mathrm{CH}_{3}\right)_{2}\right), 22.9$ $\left(\mathrm{CH}_{2}\right), 22.1\left(\mathrm{CH}_{3}\right), 21.0\left(\mathrm{CH}_{3}\right), 15.8\left(\mathrm{CH}_{3}\right)$. HRMS (ES): calcd for $\mathrm{C}_{45} \mathrm{H}_{51} \mathrm{NO}_{7} \mathrm{NH}_{4}^{+}$735.4004; found 735.4008.

L-Menthyl 3,4,6-Tri-O-benzyl-2-O-(p-methoxybenzoyl)- $\beta$-D-glucopyranoside (10). White solid, $66 \mathrm{mg}, 93 \%$.

$R_{\mathrm{f}}$ (pentane/EtOAc, 5:1) 0.63. $[\alpha]_{\mathrm{D}}{ }^{295 \mathrm{~K}}-3.0$ (c 1.0, $\mathrm{CHCl}_{3}$ ). $M_{\mathrm{p}}$ (uncorr.) 86.0-88.1 ${ }^{\circ} \mathrm{C} .{ }^{1} \mathrm{H}$ NMR (400 MHz, $\left.\mathrm{CDCl}_{3}\right) \delta_{\mathrm{H}} 7.95(\mathrm{~d}, J 8.4 \mathrm{~Hz}, 2 \mathrm{H}, \mathrm{ArH}), 7.37-7.06(\mathrm{~m}, 15 \mathrm{H}$, $\operatorname{ArH}$ ), 6.88 (d, J $8.4 \mathrm{~Hz}, 2 \mathrm{H}, \mathrm{ArH}$ ), 5.17 (t, J $8.5 \mathrm{~Hz}, 1 \mathrm{H}, \mathrm{H} 2)$, 4.80 (d, J $10.8 \mathrm{~Hz}, 1 \mathrm{H}, \mathrm{CHHPh}), 4.69$ (d, J $11.3 \mathrm{~Hz}, 1 \mathrm{H}$, CHHPh), 4.63 (d, J $12.3 \mathrm{~Hz}, 1 \mathrm{H}, \mathrm{CHHPh}), 4.61$ (d, J $11.3 \mathrm{~Hz}$, 1H, CHHPh), 4.60 (d, J $10.8 \mathrm{~Hz}, 1 \mathrm{H}, \mathrm{CHHPh}), 4.54$ (d, J 12.3 $\mathrm{Hz}, 1 \mathrm{H}, \mathrm{CHHPh}), 4.53$ (d, J $7.7 \mathrm{~Hz}, 1 \mathrm{H}, \mathrm{H1}), 3.83(\mathrm{~s}, 3 \mathrm{H}$, $\left.\mathrm{OCH}_{3}\right), 3.77(\mathrm{t}, J 9.0 \mathrm{~Hz}, 1 \mathrm{H}, \mathrm{H} 3), 3.74-3.66(\mathrm{~m}, 3 \mathrm{H}, \mathrm{H} 4$, H6a, H6b), 3.51-3.45 (m, 1H, H5), 3.36 (td, J 10.8, $4.2 \mathrm{~Hz}$, $1 \mathrm{H}, \mathrm{OCH}), 2.34-2.20(\mathrm{~m}, 1 \mathrm{H}), 1.85(\mathrm{~d}, J 12.4 \mathrm{~Hz}, 1 \mathrm{H}), 1.53$ (d, J $10.0 \mathrm{~Hz}, 2 \mathrm{H}), 1.23(\mathrm{~m}, 2 \mathrm{H}), 1.11(\mathrm{t}, J 11.3 \mathrm{~Hz}, 1 \mathrm{H})$, 0.93-0.85 (m, 1H), $0.82\left(\mathrm{~d}, J 7.1 \mathrm{~Hz}, 3 \mathrm{H}, \mathrm{CH}_{3}\right), 0.74(\mathrm{~d}, 6.8$ $\left.\mathrm{Hz}, 3 \mathrm{H}, \mathrm{CH}_{3}\right), 0.71$ (d, $\left.6.5 \mathrm{~Hz}, 3 \mathrm{H}, \mathrm{CH}_{3}\right), 0.66-0.54(\mathrm{~m}, 1 \mathrm{H})$. ${ }^{13} \mathrm{C}$ NMR $\left(101 \mathrm{MHz}, \mathrm{CDCl}_{3}\right) \delta_{\mathrm{C}} 165.0(\mathrm{C}=\mathrm{O}), 163.5(\mathrm{ArC}-$ $\mathrm{OMe}$ ), 138.5, 138.2, 138.1, 131.9-127.6, 122.8, 113.6 (Ar), 99.3 (C1), 83.1 (C3), 78.7 (OCH), 78.2 (C4), 75.4 (C5), 75.1 $\left(\mathrm{CH}_{2} \mathrm{Ph}\right), 74.9\left(\mathrm{CH}_{2} \mathrm{Ph}\right), 73.9(\mathrm{C} 2), 73.8\left(\mathrm{CH}_{2} \mathrm{Ph}\right), 69.3(\mathrm{C} 6)$, $55.5\left(\mathrm{OCH}_{3}\right), 47.4,41.1\left(\mathrm{CH}_{2}\right), 34.3\left(\mathrm{CH}_{2}\right), 31.4,25.1,23.1$ $\left(\mathrm{CH}_{2}\right), 22.2\left(\mathrm{CH}_{3}\right), 21.1\left(\mathrm{CH}_{3}\right), 15.9\left(\mathrm{CH}_{3}\right)$. HRMS (ES): calcd for $\mathrm{C}_{45} \mathrm{H}_{54} \mathrm{O}_{8} \mathrm{NH}_{4}^{+} 740.4157$ found; 740.4166 .

L-Menthyl 3,4,6-Tri-O-benzyl-2-O-(p-pyrrolidinobenzoyl)- $\beta$-D-glucopyranoside (11). Colorless oil, $64 \mathrm{mg}, 83 \%$.

$R_{\mathrm{f}}$ (pentane/EtOAc 4:1) 0.42. $[\alpha]_{\mathrm{D}}{ }^{295 \mathrm{~K}}-2.0\left(c 1.0, \mathrm{CHCl}_{3}\right)$. ${ }^{1} \mathrm{H}$ NMR $\left(400 \mathrm{MHz}, \mathrm{CDCl}_{3}\right) \delta_{\mathrm{H}} 7.85(\mathrm{~d}, J 8.9 \mathrm{~Hz}, 2 \mathrm{H}, \mathrm{ArH})$, 7.28-7.05 (m, 19H, ArH), 6.42 (d, J $8.9 \mathrm{~Hz}, 2 \mathrm{H}, \mathrm{ArH}), 5.12$ (dd, J 9.0, 8.3 Hz, 1H, H2), 4.75 (d, J $10.9 \mathrm{~Hz}, 1 \mathrm{H}, \mathrm{CHHPh})$, 4.60 (s, 2H, $\mathrm{CH}_{2} \mathrm{Ph}$ ), 4.55 (d, J $\left.12.4 \mathrm{~Hz}, 1 \mathrm{H}, \mathrm{CHHPh}\right), 4.52$ (d, J $11.4 \mathrm{~Hz}, 1 \mathrm{H}, \mathrm{CHHPh}), 4.49$ (d, J $7.5 \mathrm{~Hz}, 1 \mathrm{H}, \mathrm{H1}), 4.48$ (d, J $12.4 \mathrm{~Hz}, 1 \mathrm{H}, \mathrm{CHHPh}), 3.72(\mathrm{t}, J 9.1 \mathrm{~Hz}, 1 \mathrm{H}, \mathrm{H} 3), 3.67-$ 3.60 (m, 3H, H4, H6a, H6b), 3.43 (m, 1H, H5), 3.35-3.24 $\left(\mathrm{m}, 5 \mathrm{H}, \mathrm{OCH}, 2 \times \mathrm{N}-\mathrm{CH}_{2}\right), 2.25$ (dsep, J 7.0, $2.4 \mathrm{~Hz}, 1 \mathrm{H}$, $\left.\mathrm{CH}\left(\mathrm{CH}_{3}\right)_{2}\right), 2.01-1.89\left(\mathrm{~m}, 4 \mathrm{H}, 2 \times \mathrm{CH}_{2}\right), 1.84(\mathrm{~d}, J 12.5 \mathrm{~Hz}$, $1 \mathrm{H}), 1.52-1.43(\mathrm{~m}, 2 \mathrm{H}), 1.26-1.13(\mathrm{~m}, 1 \mathrm{H}), 1.12-1.01(\mathrm{~m}$, $1 \mathrm{H}), 0.91-0.79(\mathrm{~m}, 1 \mathrm{H}), 0.76\left(\mathrm{~d}, J 7.1 \mathrm{~Hz}, 1 \mathrm{H}, \mathrm{CH}_{3}\right), 0.69$ (d, J $\left.7.0 \mathrm{~Hz}, 1 \mathrm{H}, \mathrm{CH}_{3}\right), 0.68$ (d, J $\left.6.5 \mathrm{~Hz}, 3 \mathrm{H}, \mathrm{CH}_{3}\right), 0.67-0.52$ (m, 2H). ${ }^{13} \mathrm{C}$ NMR (101 MHz, $\left.\mathrm{CDCl}_{3}\right) \delta_{\mathrm{C}} 165.7(\mathrm{C}=\mathrm{O})$, $150.9,138.4,138.2,138.2,131.7,128.4-127.5,116.4,110.6$ (Ar), 99.3 (C1), 83.3 (C3), $78.5(\mathrm{OCH}), 78.0$ (C4), 75.2 (C5), $75.0\left(\mathrm{CH}_{2} \mathrm{Ph}\right), 74.8\left(\mathrm{CH}_{2} \mathrm{Ph}\right), 73.7\left(\mathrm{CH}_{2} \mathrm{Ph}\right), 73.4(\mathrm{C} 2)$, 69.4 (C6), $47.6\left(\mathrm{CH}_{2}-\mathrm{CH}_{2}-\mathrm{CH}_{2}-\mathrm{CH}_{2}\right), 47.3,40.9\left(\mathrm{CH}_{2}\right)$, $34.2\left(\mathrm{CH}_{2}\right), 31.4,25.5\left(\mathrm{CH}_{2}-\mathrm{N}-\mathrm{CH}_{2}\right), 25.0,23.0\left(\mathrm{CH}_{2}\right), 22.2$ $\left(\mathrm{CH}_{3}\right), 21.1\left(\mathrm{CH}_{3}\right), 15.8\left(\mathrm{CH}_{3}\right)$. HRMS (ES): calcd for $\mathrm{C}_{48} \mathrm{H}_{59} \mathrm{NO}_{7} \mathrm{NH}_{4}^{+}$784.4184; found 784.4192.

Phenyl 3,4,6-Tri-O-benzyl-2-O-(p-methoxybenzoyl)1-thio- $\boldsymbol{\alpha}$-D-glucopyranoside (12). The 2-hydroxyl was dissolved in anhydrous $\mathrm{CH}_{2} \mathrm{Cl}_{2}(2 \mathrm{~mL})$ and DMAP $(28 \mathrm{mg}$, $0.23 \mathrm{mmol}, 0.5$ equiv.) and $\mathrm{Et}_{3} \mathrm{~N}(0.32 \mathrm{~mL}, 2.3 \mathrm{mmol}, 5$ equiv.) were added, followed by 4-methoxybenzoyl chloride ( $0.3 \mathrm{~g}, 1.8 \mathrm{mmol}, 4$ equiv.). The slurry, mixture was stirred at $\mathrm{rt}$ for $18 \mathrm{~h}$ under $\mathrm{N}_{2}$ atmosphere and then quenched by the addition of $\mathrm{DMAPA}^{10}(0.23 \mathrm{~mL}, 1.8 \mathrm{mmol}, 4$ equiv. $)$. The reaction mixture was stirred with DMAPA for 10 min before washing with aq. $1 \mathrm{M} \mathrm{HCl}$ (three times), sat. aq. $\mathrm{NaHCO}_{3}$ and brine. The organic phase was dried over $\mathrm{MgSO}_{4}$, filtered, and concentrated in vacuo. The residue was purified by flash column chromatography (pentane/EtOAc 20:1 to 9:1) to yield the product $\left(155 \mathrm{mg}, 0.23 \mathrm{mmol}\right.$ ) as a syrup in $50 \%$ yield. $R_{\mathrm{f}}$ (EtOAc/pentane 9:1) 0.25. $[\alpha]_{\mathrm{D}}{ }^{295 \mathrm{~K}} 107\left(c\right.$ 1.0, $\left.\mathrm{CHCl}_{3}\right) .{ }^{1} \mathrm{H}$ NMR $\left(400 \mathrm{MHz}, \mathrm{CDCl}_{3}\right) \delta_{\mathrm{H}} 7.94(\mathrm{~d}, J 8.9 \mathrm{~Hz}, 2 \mathrm{H}, \mathrm{ArH}), 7.32$ (dd, J 6.5, 3.1 Hz, 2H, ArH), 7.27-7.05 (m, 18H, ArH), 6.83 (d, J $8.9 \mathrm{~Hz}, 1 \mathrm{H}, \mathrm{ArH}), 5.89$ (d, J $5.6 \mathrm{~Hz}, 1 \mathrm{H}, \mathrm{H1}), 5.30$ (dd, $J$ 10.0, 5.6 Hz, 1H, H2), 4.82-4.69 (m, 3H, $\mathrm{PhHH}), 4.53$ (d, J $12.0 \mathrm{~Hz}, 1 \mathrm{H}, \mathrm{CHHPh}$ ), 4.46 (d, J $10.8 \mathrm{~Hz}, 1 \mathrm{H}, \mathrm{CHHPh}$ ), 4.39-4.30 (m, 2H, CHHPh, H5), $4.02(\mathrm{t}, J 9.5 \mathrm{~Hz}, 1 \mathrm{H}, \mathrm{H} 3)$, 3.81-3.69 (m, 5H, H4, H6a, $\mathrm{CH}_{3} \mathrm{O}$ ), 3.58 (dd, J 10.8, $1.7 \mathrm{~Hz}$, $1 \mathrm{H}, \mathrm{H} 6 \mathrm{~b}) .{ }^{13} \mathrm{C}$ NMR $\left(101 \mathrm{MHz}, \mathrm{CDCl}_{3}\right) \delta_{\mathrm{C}} 165.2,163.7$, $138.1,138.1,137.9,133.6,132.0,131.9,129.0,128.5,128.4$, 128.0, 127.9, 127.9, 127.8, 127.7, 127.4, 122.0, 113.9 (Ar), 86.1 (C1), 80.9 (C3), 77.8 (C4), $75.7\left(\mathrm{CH}_{2} \mathrm{Ph}\right), 75.3\left(\mathrm{CH}_{2} \mathrm{Ph}\right)$, $73.5\left(\mathrm{CH}_{2} \mathrm{Ph}\right), 73.4(\mathrm{C} 2), 71.5(\mathrm{C} 5), 68.5(\mathrm{C} 6), 55.5\left(\mathrm{CH}_{3} \mathrm{O}\right)$. HRMS (ES): calcd for $\mathrm{C}_{41} \mathrm{H}_{36} \mathrm{O}_{7} \mathrm{SNH}_{4}{ }^{+}$694.2833; found 694.2847.

Phenyl 3,4,6-Tri-O-benzyl-2-O-(p-cyanobenzoyl)-1thio- $\alpha$-D-glucopyranoside (13). The 2-hydroxyl glycoside ${ }^{8}$ was dissolved in anhydrous $\mathrm{CH}_{2} \mathrm{Cl}_{2}(2 \mathrm{~mL})$ and DMAP $(28$ $\mathrm{mg}, 0.23 \mathrm{mmol}, 0.5$ equiv.) and $\mathrm{Et}_{3} \mathrm{~N}(0.32 \mathrm{~mL}, 2.3 \mathrm{mmol}, 5$ equiv.) were added, followed by 4-cyanobenzoyl chloride ( 0.31 g, $1.8 \mathrm{mmol}$, 4 equiv.). The slurry, mixture was stirred at $\mathrm{rt}$ for $18 \mathrm{~h}$ under $\mathrm{N}_{2}$ atmosphere and then quenched by the addition of DMAPA (0.23 mL, $1.8 \mathrm{mmol}, 4$ equiv.). The reaction mixture was stirred with $\mathrm{DMAPA}^{10}$ for 10 min before washing with aq. $1 \mathrm{M} \mathrm{HCl}$ (three times), sat. aq. $\mathrm{NaHCO}_{3}$, and brine. The organic phase was dried over $\mathrm{MgSO}_{4}$, filtered, and concentrated in vacuo. The residue was purified by flash column chromatography (pentane/EtOAc 20:1 to 9:1) to yield the product $(215 \mathrm{mg}, 0.23 \mathrm{mmol})$ as a syrup in $70 \%$ yield. $R_{\mathrm{f}}$ (EtOAc/pentane 8:1) 0.36. $[\alpha]_{\mathrm{D}}{ }^{295 \mathrm{~K}} 126\left(\right.$ c 1.0, $\left.\mathrm{CHCl}_{3}\right) .{ }^{1} \mathrm{H}$ NMR $\left(400 \mathrm{MHz}, \mathrm{CDCl}_{3}\right) \delta_{\mathrm{H}} 8.12(\mathrm{~d}, J 8.4 \mathrm{~Hz}, 2 \mathrm{H}, \mathrm{ArH}), 7.78$ (d, J $8.4 \mathrm{~Hz}, 2 \mathrm{H}, \mathrm{ArH}), 7.49-7.44(\mathrm{~m}, 2 \mathrm{H}, \operatorname{ArH}), 7.43-7.33$ $(\mathrm{m}, 8 \mathrm{H}, \mathrm{ArH}), 7.31-7.22(\mathrm{~m}, 10 \mathrm{H}), 7.31-7.22(\mathrm{~m}, 10 \mathrm{H}$, $\mathrm{ArH}$ ), 6.00 (d, J 5.7 Hz, 1H, H1), 5.45 (dd, J 10.0, 5.7 Hz, 1H, $\mathrm{H} 2$ ), 4.94 (d, J $11.4 \mathrm{~Hz}, 1 \mathrm{H}, \mathrm{CHHPh}), 4.91$ (d, J $10.8 \mathrm{~Hz}, 1 \mathrm{H}$, CHHPh), 4.83 (d, J 11.4 Hz, 1H, CHHPh), 4.70 (d, J $12.0 \mathrm{~Hz}$, 1H, CHHPh), 4.63 (d, J $10.7 \mathrm{~Hz}, 1 \mathrm{H}, \mathrm{CHHPh}), 4.53$ (d, J 12.0 $\mathrm{Hz}, 1 \mathrm{H}, \mathrm{CHHPh}), 4.51-4.46(\mathrm{~m}, 1 \mathrm{H}, \mathrm{H} 5), 4.16$ (t, J $9.3 \mathrm{~Hz}$, $1 \mathrm{H}, \mathrm{H} 3$ ), 3.95 (d, J $9.8 \mathrm{~Hz}, 1 \mathrm{H}, \mathrm{H} 4), 3.91$ (dd, $J 7.5,3.3 \mathrm{~Hz}$, $1 \mathrm{H}, \mathrm{H} 6 \mathrm{a}), 3.74$ (dd, $J 10.8,1.8 \mathrm{~Hz}, 1 \mathrm{H}, \mathrm{H} 6 \mathrm{~b}) .{ }^{13} \mathrm{C}$ NMR (101 $\left.\mathrm{MHz}, \mathrm{CDCl}_{3}\right) \delta_{\mathrm{C}} 164.0(\mathrm{C}=\mathrm{O}), 138.0,137.9,137.8,133.4$, 
$133.2,132.4,131.9,130.4,129.1,128.6,128.5,128.0,128.0$, 127.8, 127.8, 127.6, 118.0, 116.7 (Ar), 85.8 (C1), 80.7 (C3), 78.0 (C4), $75.6\left(\mathrm{CH}_{2} \mathrm{Ph}\right), 75.3\left(\mathrm{CH}_{2} \mathrm{Ph}\right), 74.0$ (C2), 73.5 $\left(\mathrm{CH}_{2} \mathrm{Ph}\right.$ ), 71.6 (C5), 68.3 (C6). HRMS (ES): calcd for $\mathrm{C}_{41} \mathrm{H}_{33} \mathrm{NO}_{6} \mathrm{SNH}_{4}^{+}$689.2680; found 689.2682.

\section{ASSOCIATED CONTENT}

\section{S Supporting Information}

The Supporting Information is available free of charge on the ACS Publications website at DOI: 10.1021/acsomega. 8 b00880.

Glycosylation results under a noncompetitive setting and ${ }^{1} \mathrm{H}$ and ${ }^{13} \mathrm{C}$ spectra of compounds (PDF)

\section{AUTHOR INFORMATION}

\section{Corresponding Author}

*E-mail: hhj@chem.au.dk.

\section{ORCID $\odot$}

Henrik H. Jensen: 0000-0003-2738-4502

Notes

The authors declare no competing financial interest.

\section{ACKNOWLEDGMENTS}

We are grateful for the financial support from The Villum Foundation (VKR023110). Associate Prof. Christian Marcus Pedersen is furthermore acknowledged for fruitful discussion and Malthe Hansen-Bruhn for graphical support.

\section{REFERENCES}

(1) Heuckendorff, M.; Pedersen, C. M.; Bols, M. Quantifying Electronic Effects of Common Carbohydrate Protecting Groups in a Piperidine Model System. Chem. - Eur. J. 2010, 16, 13982-13994.

(2) Mootoo, D. R.; Konradsson, P.; Udodong, U.; Fraser-Reid, B. Armed and disarmed n-pentenyl glycosides in saccharide couplings leading to oligosaccharides. J. Am. Chem. Soc. 1988, 110, 5583-5584.

(3) Also protecting groups as cyclic acetals and silyl ethers are often used in glycosylation chemistry. These also cause variations in glycosyl donors reactivity as well as benzyl ether substitution, see (a) Jensen, H. H.; Nordstrøm, L. U.; Bols, M. The Disarming Effect of the 4,6-Acetal Group on Glycoside Reactivity: Torsional or Electronic? J. Am. Chem. Soc. 2004, 126, 9205-9213. (b) Jensen, H. H.; Pedersen, C. M.; Bols, M. Going to Extremes: "Super" Armed Glycosyl Donors in Glycosylation Chemistry. Chem. - Eur. J. 2007, 13, $7576-7582$.

(4) (a) Douglas, N. L.; Ley, S. V.; Lücking, U.; Warriner, S. L. Tuning glycoside reactivity: New tool for efficient oligosaccharide synthesis. J. Chem. Soc., Perkin Trans. 1 1998, 51-66. (b) Zhang, Z.; Ollmann, I. R.; Ye, X.-S.; Wischnat, R.; Baasov, T.; Wong, C.-H. Programmable One-Pot Oligosaccharide Synthesis. J. Am. Chem. Soc. 1999, 121, 734-753.

(5) Heuckendorff, M.; Poulsen, L. T.; Jensen, H. H. Remote Electronic Effects by Ether Protecting Groups Fine-Tune Glycosyl Donor Reactivity. J. Org. Chem. 2016, 81, 4988-5006.

(6) Heuckendorff, M.; Pedersen, C. M.; Bols, M. The Influence of Neighboring Group Participation on the Hydrolysis of 2-OSubstituted Methyl Glucopyranosides. Org. Lett. 2011, 13, 59565959.

(7) (a) Mydock, L. K.; Demchenko, A. V. Superarming the S -Benzoxazolyl Glycosyl Donors by Simple 2-O-Benzoyl-3,4,6-tri- O -benzyl Protection. Org. Lett. 2008, 10, 2103-2106. (b) Mydock, L. K.; Demchenko, A. V. Application of the Superarmed Glycosyl Donor to Chemoselective Oligosaccharide Synthesis. Org. Lett. 2008, 10, 2107-2110.

(8) In our definition of superarmed we require the donor to be significantly more reactive than an armed donor, see Poulsen, L. T.;
Heuckendorff, M.; Jensen, H. H. On the generality of the superarmament of glycosyl donors. Org. Biomol. Chem. 2018, 16, 2269-2276.

(9) Poulsen, L. T.; Heuchendorff, M.; Hedberg, C.; Jensen, H. H. Dissection of the effects that govern thioglucoside and thiomannoside reactivity. Org. Biomol. Chem. 2018, 16, 2277-2288.

(10) Andersen, S. M.; Heuckendorff, M.; Jensen, H. H. 3(Dimethylamino)-1-propylamine: A Cheap and Versatile Reagent for Removal of Byproducts in Carbohydrate Chemistry. Org. Lett. 2015, 17, 944-947.

(11) Viuff, A. H.; Heuckendorff, M.; Jensen, H. H. p-Chlorobenzyl Ether: A p-Methoxybenzyl Ether in Disguise. Org. Lett. 2016, 18, 5773-5775.

(12) Cheung, C. W.; Buchwald, S. L. Mild and General PalladiumCatalyzed Synthesis of Methyl Aryl Ethers Enabled by the Use of a Palladacycle Precatalyst. Org. Lett. 2013, 15, 3998-4001.

(13) Senecal, T. D.; Shu, W.; Buchwald, S. L. A General, Practical Palladium-Catalyzed Cyanation of (Hetero)Aryl Chlorides and Bromides. Angew. Chem., Int. Ed. 2013, 52, 10035-10039.

(14) Bruno, N. C.; Tudge, M. T.; Buchwald, S. L. Design and preparation of new palladium precatalysts for $\mathrm{C}-\mathrm{C}$ and $\mathrm{C}-\mathrm{N}$ crosscoupling reactions. Chem. Sci. 2013, 4, 916-920.

(15) C-13 NMR spectroscopic integration is a valid method for obtaining product ratios of diastereomeric pairs, see Otte, D. A. L.; Borchmann, D. E.; Lin, C.; Weck, M.; Woerpel, K. A. 13 C NMR Spectroscopy for the Quantitative Determination of Compound Ratios and Polymer End Groups. Org. Lett. 2014, 16, 1566-1569.

(16) Hassner, A.; Krepski, L. R.; Alexanian, V. Aminopyridines as acylation catalysts for tertiary alcohols. Tetrahedron 1978, 34, 20692076.

(17) Hansch, C.; Leo, A.; Taft, R. W. A survey of Hammett substituent constants and resonance and field parameters. Chem. Rev. 1991, 91, 165-195.

(18) Li, X.; Huang, L.; Hu, X.; Huang, X. Thio-arylglycosides with various aglyconpara-substituents: a probe for studying chemical glycosylation reactions. Org. Biomol. Chem. 2009, 7, 117-127.

(19) Ennis, S.; Fairbanks, A.; Slinn, C.; Tennant-Eyles, R.; Yeates, H. N-Iodosuccinimide-mediated intramolecular aglycon delivery. Tetrahedron 2001, 57, 4221-4230. 